\title{
Efficient Constitutive Expression of Cellulolytic Enzymes in Penicillium oxalicum for Improved Efficiency of Lignocellulose Degradation
}

\author{
Pankajkumar Ramdas Waghmare ${ }^{1}$, Pratima Pankajkumar Waghmare ${ }^{1}$, Liwei Gao ${ }^{1,2}$, Wan Sun ${ }^{1,3}$, \\ Yuqi Qin ${ }^{1,3}$, Guodong Liu ${ }^{1,3 *}$, and Yinbo Qu ${ }^{1,3}$ \\ 'State Key Laboratory of Microbial Technology, Shandong University, Shandong 266237, P. R. China \\ ${ }^{2}$ Tobacco Research Institute of Chinese Academy of Agricultural Sciences, Shandong 266101, P. R. China \\ ${ }^{3}$ National Glycoengineering Research Center, Shandong University, Shandong 266237, P. R. China
}

\begin{abstract}
Efficient cellulolytic enzyme production is important for the development of lignocellulosedegrading enzyme mixtures. However, purification of cellulases from their native hosts is time- and labor-consuming. In this study, a constitutive expression system was developed in Penicillium oxalicum for the secreted production of proteins. Using a constitutive polyubiquitin gene promoter and cultivating with glucose as the sole carbon source, nine cellulolytic enzymes of different origins with relatively high purity were produced within $48 \mathrm{~h}$. When supplemented to a commercial cellulase preparation, cellobiohydrolase I from $P$. funiculosum and cellobiohydrolase II from Talaromyces verruculosus showed remarkable enhancing effects on the hydrolysis of steam-exploded corn stover. Additionally, a synergistic effect was observed for these two cellobiohydrolases during the hydrolysis. Taken together, the constitutive expression system provides a convenient tool for the production of cellulolytic enzymes, which is expected to be useful in the development of highly efficient lignocellulose-degrading enzyme mixtures.
\end{abstract}

Keywords: Penicillium oxalicum, lignocellulose, constitutive expression system, cellulase, enzymatic conversion

Received: January 4, 2021 Accepted: March 10, 2021

First published online: March 26, 2021

*Corresponding autho Phone: +86-532-58632406 Fax: +86-532-58631501 E-mail: gdliu@sdu.edu.cn

Supplementary data for this paper are available on-line only at http://jmb.or.kr.

pISSN 1017-7825 elSSN 1738-8872

Copyright(C) 2021 by The Korean Society for Microbiology and Biotechnology

\section{Introduction}

Lignocellulosic biomass is an abundant and renewable organic resource [1]. Bioconversion of lignocellulosic biomass to biofuels and chemicals is helpful to diminish the dependency on depleting petroleum reserves [2]. However, the commercial bioconversion of lignocellulose to biofuels is still challenging due to the heterogeneous and recalcitrant nature of lignocellulosic materials $[3,4]$. Thus, a pretreatment step prior to enzymatic hydrolysis is required to alter the structure and composition of lignocellulose and, therefore, improve the efficiency of hydrolysis [5], and efficient lignocellulolytic enzyme mixtures need to be developed to lower the cost of the process [6].

Cellulose is an unbranched polysaccharide comprised of glucose subunits linked by $\beta$-1,4-glycosidic bonds and is the major constituent of most plant cell walls [7]. Generally, the enzymatic hydrolysis of cellulose involves the synergistic action of three types of core hydrolytic enzymes, namely endo- $\beta$-1,4-glucanase (EG, EC number 3.2.1.4), cellobiohydrolase ( $\mathrm{CBH}, 3.2 .1 .176 / 3.2 .1 .91)$ and $\beta$-glucosidase (BGL, 3.2.1.21), collectively known as cellulases [3]. Currently, filamentous fungi are mainly used for the industrial production of cellulases. For fungal cellulases, the EGs mostly act on internal bonds in the cellulose fiber and generates free chain ends. CBHs are processive cellulases hydrolyzing cellulose chain to cellobiose by acting on reducing ends (CBHI) or non-reducing ends (CBHII), while BGLs hydrolyze cellodextrins into glucose [8, 9]. Additionally, lytic polysaccharide monooxygenases (LPMOs, 1.14.99.54/1.14.99.56) break down cellulose using an oxidative mechanism, which can significantly enhance the action of hydrolytic enzymes [10].

Supplementation of exogenous enzymes and de novo design of enzyme cocktails are effective approaches to improve the performance of cellulase mixtures $[6,11]$. Previous studies on various cellulolytic fungi have reported a set of highly active cellulases capable of degrading crystalline cellulose more efficiently than the components in common commercial cellulases [12-15]. Many of the enzymes used in these studies were purified from the culture supernatant of their native hosts, which is a time-consuming and labor-intensive process. Therefore, the efficient production of proteins in well-established host strains is valuable for the investigation of cellulase components. Particularly, filamentous fungi are more suitable for the expression of some cellulases than bacteria and yeasts regarding their properties $[16,17]$, which highlights the importance of developing expression systems using 
natural cellulolytic fungal species.

Penicillium strains have been reported for the production of balanced lignocellulose-degrading enzyme systems with superior performances. Therefore, they are considered as potential alternatives to the industrial cellulase-producer Trichoderma reesei $[18,19]$. Penicillium oxalicum strains are commonly isolated from the natural environment for their high cellulase-producing capacities [20,21]. Genomic and proteomic analyses of a P. oxalicum wild-type strain 114-2 have revealed that it produces a lignocellulolytic enzyme system rich in hemicellulases [22]. Some P. oxalicum mutant strains have been used in industrial applications for cellulase production and lignocellulosic biomass hydrolysis [23]. Nevertheless, the cellulase system of $P$. oxalicum still needs to be improved in regard to the efficiency of crystalline cellulose degradation [24].

In this study, a constitutive protein expression system enabling the production of relatively pure cellulases was developed using $P$. oxalicum. Nine cellulolytic enzymes of different origins were expressed in this system and then investigated for their abilities to boost the efficiency of $P$. oxalicum cellulases in lignocellulose degradation.

\section{Materials and Methods}

\section{Lignocellulosic Biomass and Enzymes}

Sweet sorghum vinasse produced from continuous solid-state fermentation technology [25] was provided by Hongli Biotechnology Co. Ltd. (China). The vinasse was pretreated with $15 \%$ (w/v) ammonium sulfite with a solid to liquid ratio of $1: 4(\mathrm{w} / \mathrm{v})$ for $1 \mathrm{~h}$ at $170^{\circ} \mathrm{C}$. After the pretreatment, the solid biomass was collected and washed 8 times with distilled water to remove free sugar. A steam-exploded corn stover (SECS) was provided by COFCO Bio-chemical and Bio-energy Co. Ltd. (China). Commercial cellulase preparation SP in the form of solid powder was provided by Sino Biotechnology Co., Ltd. (China) [26].

\section{Construction of Plasmids and Strains}

To construct the gene expression vector pPubiD-pyrG, the selectable marker gene pyrG (orotidine- $5^{\prime}$ phosphate decarboxylase) from Aspergillus nidulans was inserted into the KpnI/EcoRI site of plasmid pUC19 (Tsingke, China) to generate plasmid pUC19-pyrG. The P. oxalicum ubiD gene promoter and A. nidulans trpC gene terminator were then fused together, with a $B a m H I$ site introduced between them. The fusion product was inserted and removed the BamHI site of pUC19-pyrG to generate plasmid pPubiD-pyrG. The cellulase genes from T. reesei and P. oxalicum were amplified from the genomic DNA of corresponding strains QM9414 and 1142 , respectively. The other cellulase genes were synthesized by Genewiz (China). The cellulase genes were inserted to the BamHI site of pPubiD-pyrG to produce gene-specific expression vectors. The cloning operations were performed using the ClonExpress II One Step Cloning Kit (Vazyme Biotech, China) according to the manufacturer's protocol. Escherichia coli DH5 $\alpha$ (Tsingke, China) was used for plasmid transformation and amplification. All the primers and their uses are listed in Table S1. The nucleotide sequences of cellulase genes are shown in Table S2.

The cellulase gene expression vectors were linearized using NdeI and transformed into P. oxalicum uracil auxotrophic strain M12 ( $p y r G^{-}$) [27]. PEG-mediated protoplast transformation was performed as previously described [28]. The purified transformants were confirmed by diagnostic PCR and sequencing.

\section{Enzyme Production}

The correct fungal transformants were grown on wheat bran liquor slants at $30^{\circ} \mathrm{C}$ for $4 \mathrm{~d}$, and the spores were then collected in $0.9 \%(\mathrm{w} / \mathrm{v}) \mathrm{NaCl}$ solution supplemented with $0.05 \%(\mathrm{w} / \mathrm{v})$ Tween 80 . The fungal spore suspension was inoculated to seed medium (Vogel's salt solution [28] supplemented with $20 \mathrm{~g} / \mathrm{l}$ glucose and $1 \mathrm{~g} / \mathrm{l}$ peptone) and incubated at $30^{\circ} \mathrm{C}$ with rotary shaking at $200 \mathrm{rpm}$ for $24 \mathrm{~h}$. The pre-culture was inoculated into $50 \mathrm{ml}$ fermentation medium (Vogel's salt solution supplemented with $20 \mathrm{~g} / \mathrm{lglucose}$ ) with an inoculation ratio of $10 \%$ (v/v), and cultivated under the same conditions for $48 \mathrm{~h}$. For the production of TtAA9E, $\mathrm{CuSO}_{4} \cdot 5 \mathrm{H}_{2} \mathrm{O}$ at a final concentration of $0.5 \mathrm{mg} / \mathrm{l}$ was added to fermentation media. Uracil at a final concentration of $0.5 \mathrm{~g} / \mathrm{l}$ was added to the medium if necessary. The culture was vacuum filtered through a $0.45 \mu \mathrm{m}$ polyethersulfone membrane (Xingya, China). As indicated in the text, the filtrates were concentrated by ten folds using a Macrosep Advance Centrifugal Device 30K (10K for TtAA9E; USA).

\section{Enzyme Assay, Protein Concentration Determination and SDS-PAGE}

Unless otherwise specified, endoglucanase activity (CMCase activity) was measured at $50^{\circ} \mathrm{C}$ using $1 \%(\mathrm{w} / \mathrm{v})$ sodium carboxymethyl cellulose as previously described [28]. One unit of enzyme activity was defined as the amount of enzyme required to liberate $1 \mu \mathrm{M}$ of glucose equivalent per minute under the standard assay conditions. For TaEG, the optimum temperature was determined by measuring CMCase activities at different temperatures, and thermostability was studied by incubating the enzyme at different temperatures for $1 \mathrm{~h}$ and then measuring the CMCase activity at $50^{\circ} \mathrm{C}$. Protein concentration was determined by using a Bradford reagent kit (Sangon, China). Sodium dodecyl sulfate-polyacrylamide gel electrophoresis (SDS-PAGE) was performed using $12.5 \%(\mathrm{w} / \mathrm{v}$ ) polyacrylamide gels, and proteins were stained with Coomassie Brilliant Blue R-250 (Sangon).

\section{Liquefaction of Biomass}

The reaction system in $100 \mathrm{ml}$ flasks contained sodium acetate buffer $(50 \mathrm{mM}, \mathrm{pH} 4.8)$ and pretreated sweet sorghum vinasse at a loading of $10 \%(\mathrm{w} / \mathrm{w})$ dry matter (DM), with a total weight of $20 \mathrm{~g}$. TaEG was added at a dosage of $2 \mathrm{mg} / \mathrm{g}$ DM. The liquefaction system was incubated at stated temperatures with a shaking speed of $200 \mathrm{rpm}$. 
Enzymatic Hydrolysis

The hydrolysis system with a total weight of $30 \mathrm{~g}$ contained sodium acetate buffer ( $50 \mathrm{mM}, \mathrm{pH} 4.8), 0.1 \%$ (w/w) sodium benzoate, and 5\% (w/w) DM SECS. For the cellulase supplementation experiment, cellulase preparation $\mathrm{SP}$ of $10 \mathrm{mg} / \mathrm{g}$ DM and a single cellulase component of $2 \mathrm{mg} / \mathrm{g}$ DM were added to the system. For the cellulase mixture experiment, simplex lattice mixture design was performed using the Design-Expert 8.0 software (StatEase Inc., USA), with the sum of the three enzyme components always being $10 \mathrm{mg} / \mathrm{g} \mathrm{DM}$. The hydrolysis was performed in $100 \mathrm{ml}$ flasks incubated at $50^{\circ} \mathrm{C}$ with a shaking speed of $200 \mathrm{rpm}$. The hydrolysate samples were centrifuged at $2348 \mathrm{~g}$ for $10 \mathrm{~min}$, and the concentration of glucose in the supernatant was measured using an SBA40C biosensor analyzer (BISAS, China).

\section{Results and Discussion}

\section{Construction of the Constitutive Expression Vector pPubiD-pyrG}

Similar to many other cellulolytic fungi, the expression of endogenous lignocellulolytic enzymes in P. oxalicum is repressed by glucose $[22,29]$, which provides a low background for extracellular protein production. Therefore, a constitutive gene expression vector was designed for the expression of secreted proteins in the glucose medium. The vector pPubiD-pyrG contains a constitutive strong promoter PubiD from a polyubiquitin gene [30]. A BamHI site was added downstream of $\mathrm{P} u b i \mathrm{D}$, which allows the insertion of the target gene using recombinational cloning methods (Fig. 1A).

\section{Expression and characterization of recombinant TaEG}

As a first attempt, the gene encoding TaEG from Thermoascus aurantiacus (Table 1) was inserted to the BamHI site on plasmid pPubiD-pyrG to generate pPubiD-TaEG-pyrG (Fig. 1B). The latter plasmid was linearized and transformed into uracil auxotrophic strain $P$. oxalicum M12. The gene expression cassette was expected to be integrated into the chromosomal DNA via random insertion. The correct transformants were cultivated in the medium with glucose as the sole carbon source, and the one producing the highest level of TaEG was selected for further studies. After $48 \mathrm{~h}$ of cultivation, CMCase activity of $0.95 \mathrm{U} / \mathrm{ml}$ and protein concentration of $1.15 \mathrm{mg} / \mathrm{ml}$ were detected in the culture supernatant, which were much higher than those at $24 \mathrm{~h}$ (Fig. 2A). SDS-PAGE showed that a single protein band was present in the culture supernatant of the TaEG-expressing strain (Fig. 2B). The apparent molecular weight was in agreement with the predicted value of the mature protein $(33.71 \mathrm{kDa})$. Interestingly, several protein bands were detected in the culture supernatant of the parent strain M12 but not in the TaEG-expressing strain, which is possibly because of the competition between TaEG and background proteins on cellular resources.

The optimum temperature for the CMCase activity of crude recombinant TaEG was $60^{\circ} \mathrm{C}$, with a relative activity of $92 \%$ detected at $70^{\circ} \mathrm{C}$ (Fig. 2B). Approximately $80 \%$ of activity was retained after incubation at $70^{\circ} \mathrm{C}$ for $2 \mathrm{~h}$, which is consistent with the TaEG properties reported by Hong et al. [31]. When the recombinant TaEG was added to ammonium sulfite-pretreated sweet sorghum vinasse, the substrate was efficiently liquefied after $2 \mathrm{~h}$ of incubation at $60^{\circ} \mathrm{C}$ (Fig. 2D), which is helpful for the saccharification at high solids loadings [32]. Taken together,

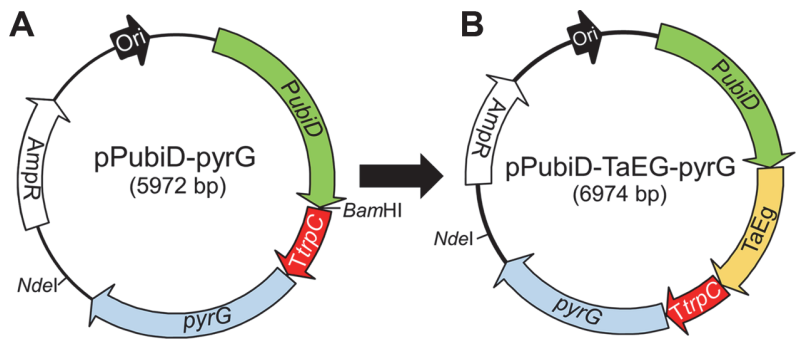

Fig. 1. Construction of gene expression vectors. (A) The map of empty vector pPubiD-pyrG. The BamHI site was used for the insertion of target genes. (B) The map of TaEG expression vector pPubiD-TaEG-pyrG. The NdeI site was used for plasmid linearization.

Table 1. Information of cellulases expressed in this study.

\begin{tabular}{clclcr}
\hline Protein name & \multicolumn{1}{c}{ Origin } & GenBank Accession No. & CAZy family & MW $(\mathrm{kDa})^{\mathrm{a}}$ & Reference \\
\hline CtCBHI & Chaetomium thermophilum & CAM98448.1 & GH7, CBM1 & 54.56 & {$[12]$} \\
PfCBHI & Penicillium funiculosum & 4XEB_A & GH7, CBM1 & 52.43 & {$[13]$} \\
TrCBHI & Trichoderma reesei & EGR44817.1 & GH7, CBM1 & 52.24 & {$[42]$} \\
PoCBHII & Penicillium oxalicum & EPS32164.1 & CBM1, GH6 & 46.56 & {$[22]$} \\
MtCBHII & Myceliophthora thermophila & AEO55787.1 & CBM1, GH6 & 49.48 & {$[43]$} \\
TvCBHII & Talaromyces verruculosus & APE61639.1 & CBM1, GH6 & 45.70 & {$[43]$} \\
TaEG & Thermoascus aurantiacus & AAL88714.2 & GH5 & 33.71 & {$[31]$} \\
TtAA9E & Thielavia terrestris & ACE10234.1 & AA9 & 22.55 & {$[44]$} \\
PoBGLI & Penicillium oxalicum & EPS27792.1 & GH3 & 91.55 & {$[45]$} \\
\hline
\end{tabular}

${ }^{a}$ Molecular weight predicted using the mature protein sequences without signal peptide 
A
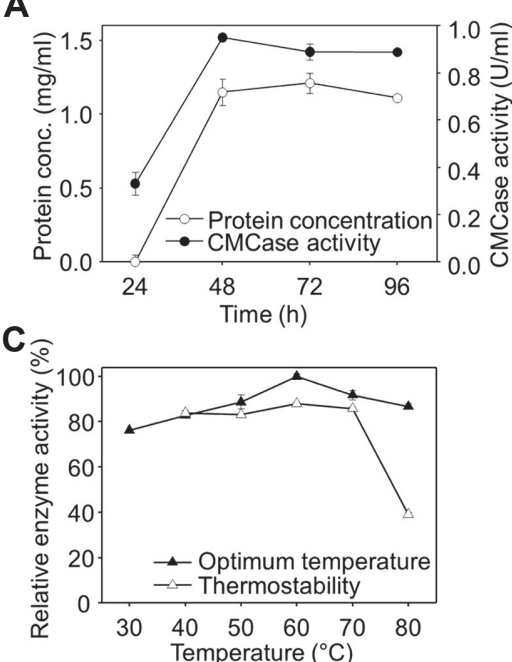

B $\frac{\mathrm{M} 12}{24487296} \frac{\mathrm{TaEG}}{24487296}$

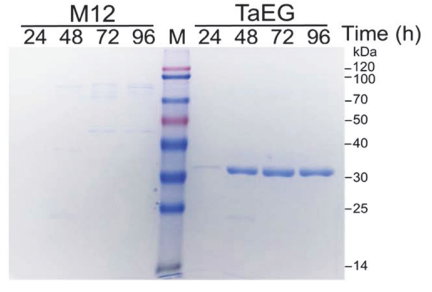

D

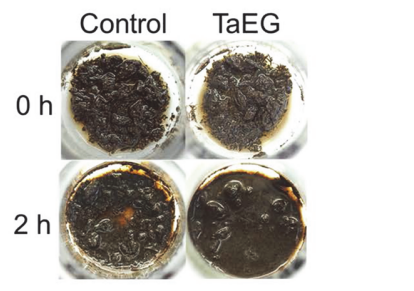

Fig. 2. Expression and characterization of recombinant TaEG in P. oxalicum. (A) Protein concentration and CMCase activity in the culture supernatant of TaEG-expressing strain. Data represent mean \pm SD from duplicate cultivations. (B) SDS-PAGE analysis of the culture supernatants of TaEG-expressing strain and parent strain M12. (C) Optimum temperature and thermostability of recombinant TaEG. Data represent mean \pm SD from duplicate reactions. (D) Liquefaction of ammonium sulfite-pretreated sweet sorghum vinasse by recombinant TaEG of $2 \mathrm{mg} / \mathrm{g} \mathrm{DM}$ at $60^{\circ} \mathrm{C}$.

recombinant TaEG with relatively high purity and reported thermostability was successfully produced using the constitutive expression system.

\section{Expression of Cellulolytic Enzymes of Different Origins}

Considering the effective production of TaEG, cellulolytic enzymes of different types and origins were expressed using the same method, respectively. These enzymes include three CBHI/Cel7A proteins, three CBHII/ Cel6A proteins, one LPMO (TtAA9E), and one BGL (Table 1). In the glucose medium, all the enzymes were expressed and secreted into the culture (Fig. 3). The addition of extra $\mathrm{CuSO}_{4}$ was found to be essential for efficient production of TtAA9E, suggesting that the copper ion is required for its correct folding or stabilization [33, 34]. Although background proteins were detected in some samples, the purity of these proteins was satisfactory for their application in lignocellulose degradation. All the enzymes, except for TaEG, exhibited apparent molecular weights larger than the predicted values (Table 1 ), which was attributed to the glycosylation of proteins. $N$-linked and $O$-linked glycosylation types have been frequently reported in the context of fungal cellulases [35]. For example, glycans on the catalytic domain and linker peptide of T. reesei $\mathrm{CBHI}$ led to 9 to $17 \mathrm{kDa}$ increases in the molecular weight [36]. For CBHI from Chaetomium thermophilum and CBHII from Myceliophthora thermophila, broad protein bands were detected by SDS-PAGE, suggesting the heterogeneity of their glycosylation [37].

\section{The Effect of Enzyme Supplementation on the Hydrolytic Efficiency of $P$. oxalicum Enzymes}

The heterologous cellulases selected for expression in this study have been reported to have the advantages of high catalytic efficiency and/or high thermostability (Table 1). For example, PfCBHI from P. funiculosum hydrolyzes cellulose faster than TrCBHI from $T$. reesei [13]. Therefore, the recombinant proteins were supplemented to the commercial cellulase preparation SP to examine whether the hydrolytic efficiency on the SECS could be improved. The recombinant proteins were loaded at $2 \mathrm{mg} / \mathrm{g} \mathrm{DM}$, which was $20 \%$ of that of SP

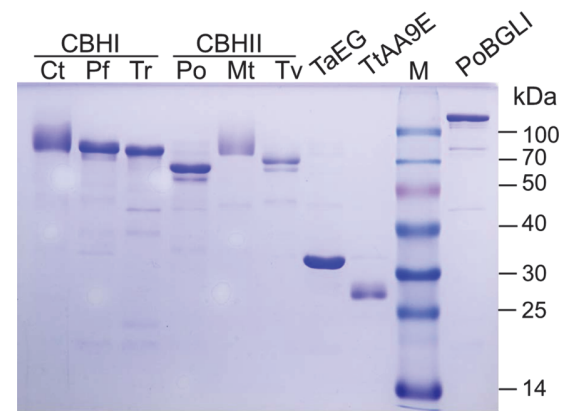

Fig. 3. SDS-PAGE analysis of recombinant cellulases. The culture supernatants were concentrated by ultra-filtration and loaded into the gel. $\mathrm{M}$, molecular weight marker. 

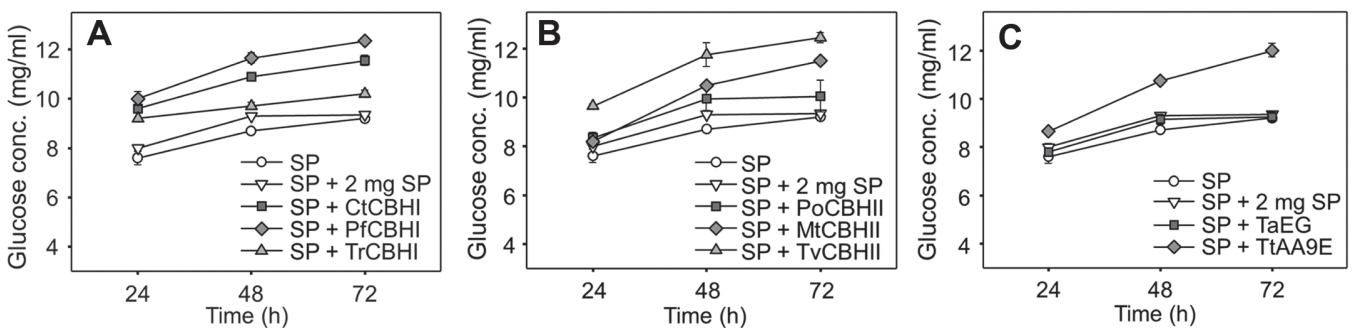

Fig. 4. Hydrolysis of SECS using commercial cellulase preparation SP supplemented with different cellulase components. SP enzyme of $10 \mathrm{mg} / \mathrm{g}$ DM supplemented with a single cellulase component of $2 \mathrm{mg} / \mathrm{g}$ DM were used for the hydrolysis. SP enzyme of $10 \mathrm{mg} / \mathrm{g}$ DM without supplementation, or supplemented with SP of $2 \mathrm{mg} / \mathrm{g}$ DM, were used as controls. Data represent mean \pm SD from duplicate reactions. (A) CBHI supplementation. (B) CBHII supplementation. (C) TaEG or TtAA9E supplementation.

(10 mg/g DM). As a control, SP of $12 \mathrm{mg} / \mathrm{g}$ DM was also used for hydrolysis, which allowed the comparison of hydrolytic efficiencies at the same protein dosage.

As shown in Fig. 4A, the supplementation of all three CBHI proteins were able to enhance the hydrolysis compared to SP enzyme of the same dosage. Among them, PfCBHI was the most effective, with a glucose concentration of $12.35 \mathrm{~g} / \mathrm{l}$ detected in the hydrolysate at $72 \mathrm{~h}, 32 \%$ higher than the control (Fig. 4A). The superior activity of PfCBHI towards crystalline cellulose over TrCBHI has been mainly attributed to two important motifs in the catalytic domain, as per the results of mutation experiments [13]. Of note, sequence alignment revealed that CtCBHI is more similar to TrCBHI at these two positions (data not shown), which might explain its lower efficiency, compared to that of PfCBHI. The three CBHII proteins and TtAA9E also showed significant enhancing effects on the hydrolysis (Figs. 4B and 4C). Particularly, TvCBHII from Talaromyces verruculosus (P. verruculosum) showed the highest efficiency, which improved the hydrolysis to a similar extent to that of PfCBHI. However, the structural basis of the high activity of TvCBHII remains to be resolved through domain-swapping and sequence mutation experiments. In contrast to $\mathrm{CBHs}$ and TtAA9E, no enhancing effect was observed when TaEG was supplemented to the hydrolysis system (Fig. 4C).

Increasing the dosage of SP from 10 to $12 \mathrm{mg} / \mathrm{g}$ DM resulted in faster hydrolysis but not higher glucose yield at $72 \mathrm{~h}$ (Fig. 4), implying that the enzyme preparation has difficulty in degrading a highly recalcitrant cellulose fraction in the SECS [24]. The results of enzyme supplementation suggested that the SP enzyme lacks adequate $\mathrm{CBH}$ and LPMO activities for the deep hydrolysis of the substrate, while the EG activity was sufficient under the experimental condition. Additionally, supplementation of PfCBHI and TvCBHII remarkably improved the release of glucose in the first $24 \mathrm{~h}$, which was consistent with their high catalytic efficiencies [15]. In summary, the study has identified effective cellulase components for enhancing the hydrolytic efficiency of SP. In the future, genes encoding these enzymes could be introduced into the high-producing strains of $P$. oxalicum for the production of highly efficient lignocellulolytic enzyme mixtures.

\section{Synergistic Effect of PfCBHI and TvCBHII in the Hydrolysis of Lignocellulosic Biomass}

The above results revealed that both PfCBHI and TvCBHII could significantly improve the hydrolytic efficiency of commercial enzyme SP. To provide further guidance for the development of lignocellulolytic enzyme mixtures, the recombinant enzymes PfCBHI, TvCBHII and TaEG were mixed together and used for the hydrolysis of SECS. The artificial enzyme mixtures of different compositions were loaded at $10 \mathrm{mg} / \mathrm{g} \mathrm{DM}$ (Table 2). To avoid the inhibition of cellulase by cellobiose, PoBGLI of $2 \mathrm{mg} / \mathrm{g}$ DM was added to all the hydrolysis systems. Generally, the enzyme mixtures showed similar or higher hydrolytic efficiencies compared to those of SP supplemented with single cellulase components (Fig. 4). Among the ten kinds of enzyme mixtures, number 7 and 8 produced the highest yields of glucose, while the yields of number 3 and 4 were the lowest. Therefore, PfCBHI and TvCBHII

Table 2. Hydrolysis of SECS by different enzyme mixtures. Data represent mean \pm SD from duplicate reactions.

\begin{tabular}{ccccccc}
\hline \multirow{2}{*}{$\begin{array}{c}\text { Mixture } \\
\text { number }\end{array}$} & \multicolumn{3}{c}{ Enzyme dosage (mg/g DM) } & \multicolumn{3}{c}{ Glucose concentration (g/l) } \\
\cline { 2 - 7 } & PfCBHI & TvCBHII & TaEG & $24 \mathrm{~h}$ & $48 \mathrm{~h}$ & $72 \mathrm{~h}$ \\
\hline 1 & 2.17 & 2.17 & 5.67 & $11.50 \pm 0.14$ & $11.70 \pm 0.42$ & $13.00 \pm 0.28$ \\
2 & 1.00 & 4.50 & 4.50 & $10.65 \pm 0.21$ & $11.15 \pm 0.64$ & $12.10 \pm 0.00$ \\
3 & 1.00 & 1.00 & 8.00 & $9.95 \pm 0.35$ & $10.70 \pm 0.00$ & $11.75 \pm 0.49$ \\
4 & 1.00 & 8.00 & 1.00 & $9.90 \pm 0.42$ & $10.80 \pm 0.42$ & $12.05 \pm 0.07$ \\
5 & 2.17 & 5.67 & 2.17 & $11.10 \pm 0.28$ & $12.00 \pm 0.42$ & $13.65 \pm 0.21$ \\
6 & 8.00 & 1.00 & 1.00 & $11.80 \pm 0.28$ & $12.55 \pm 0.35$ & $13.70 \pm 0.14$ \\
7 & 4.50 & 4.50 & 1.00 & $12.45 \pm 1.06$ & $12.90 \pm 0.42$ & $14.65 \pm 0.78$ \\
8 & 5.67 & 2.17 & 2.17 & $11.80 \pm 0.71$ & $12.70 \pm 0.14$ & $14.70 \pm 1.27$ \\
9 & 4.50 & 1.00 & 4.50 & $12.00 \pm 0.85$ & $12.00 \pm 0.42$ & $13.65 \pm 0.07$ \\
10 & 3.33 & 3.33 & 3.33 & $11.45 \pm 0.07$ & $12.40 \pm 0.14$ & $13.45 \pm 0.64$ \\
\hline
\end{tabular}




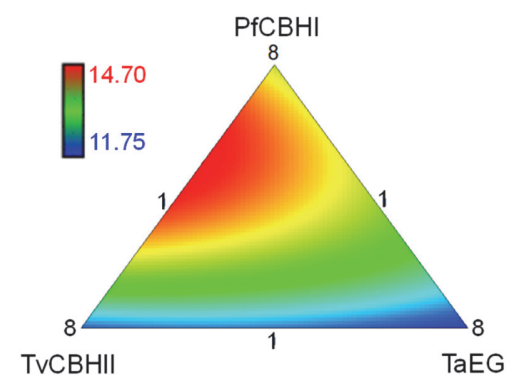

Fig. 5. Ternary contour plot of the glucose yields produced by cellulase mixtures. SECS with 5\% DM was hydrolyzed for $72 \mathrm{~h}$.

played important roles in the hydrolysis of SECS. Moreover, the two CBH proteins had a synergistic effect on the degradation (Fig. 5). The synergism between CBHI and CBHII with regard to crystalline cellulose has been reported since 1980 [38]; however, the mechanism underlying this phenomenon has remained unclear. A recent study by Badino et al. suggested that this exo-exo synergy is likely due to their different substrate specificities involving the cellulose-binding domain and linker, rather than their weak endo-acting activities [39].

A synergistic effect was hardly observed between CBH proteins and TaEG, probably because the dosage of TaEG in all combinations ( $>1 \mathrm{mg} / \mathrm{g} \mathrm{DM}$ ) was sufficient for the hydrolysis. Nevertheless, the TaEG used in this study belongs to glycosyl hydrolase family 5 [40], while an EG belonging to family 7 has been reported to be important for the hydrolysis of steam exploded wheat straw [41]. Therefore, family 7 EGs could be included in the study of artificial cellulase mixtures in the future.

In conclusion, in this study, we have developed a constitutive expression system for the fast and convenient production of cellulolytic enzymes. The produced enzymes have relatively high purity, which enabled further characterization of enzymes and the construction of artificial cellulase mixtures. Using this system, two CBH proteins and an LPMO were found to remarkably boost the hydrolytic efficiency of a commercial cellulase preparation; of note, they are expected to be co-expressed in production strains in the future. The results provide direction to genetically engineer strains for on-site production of highly efficient lignocellulolytic enzymes.

\section{Acknowledgments}

This work was supported by National Key R\&D Program of China Grant (2018YFA0900500), Major Basic Research Program of Shandong Provincial Natural Science Foundation (ZR2019ZD19), the Key Research and Development Project of Shandong Province (2019JZZY020223 and 2019JZZY020807), the Young Scholars Program of Shandong University (YSPSDU) (to G. L.), and the China/Shandong University International Postdoctoral Exchange Program.

\section{Conflict of Interest}

The authors have no financial conflicts of interest to declare.

\section{References}

1. Kumar A, Gautam A, Dutt D. 2016. Biotechnological transformation of lignocellulosic biomass in to industrial products: an overview. Adv. Biosci. Biotechnol. 07: 149-168.

2. Paulova L, Patakova P, Branska B, Rychtera M, Melzoch K. 2015. Lignocellulosic ethanol: Technology design and its impact on process efficiency. Biotechnol. Adv. 33: 1091-1107.

3. Himmel ME, Ding SY, Johnson DK, Adney WS, Nimlos MR, Brady JW, et al. 2007. Biomass recalcitrance: engineering plants and enzymes for biofuels production. Science 315: 804-807.

4. Balan V. 2014. Current challenges in commercially producing biofuels from lignocellulosic biomass. ISRN Biotechnol. $2014: 463074$.

5. Karimi K, Taherzadeh MJ. 2016. A critical review of analytical methods in pretreatment of lignocelluloses: Composition, imaging, and crystallinity. Bioresour. Technol. 200: 1008-1018.

6. Liu G, Qin Y, Li Z, Qu Y. 2013. Development of highly efficient, low-cost lignocellulolytic enzyme systems in the post-genomic era. Biotechnol. Adv. 31: 962-975.

7. Burchard W, Schulz L. 1995. Functionality of the $\beta(1,4)$ glycosidic linkage in polysaccharides. Macromol. Symp. 99: 57-69.

8. Warden AC, Little BA, Haritos VS. 2011. A cellular automaton model of crystalline cellulose hydrolysis by cellulases. Biotechnol. Biofuels 4: 39.

9. Percival Zhang YH, Himmel ME, Mielenz JR. 2006. Outlook for cellulase improvement: Screening and selection strategies. Biotechnol. Adv. 24: 452-481.

10. Hemsworth GR, Johnston EM, Davies GJ, Walton PH. 2015. Lytic polysaccharide monooxygenases in biomass conversion. Trends Biotechnol. 33: 747-761.

11. Merino ST, Cherry J. 2007. Progress and challenges in enzyme development for biomass utilization. Adv. Biochem. Eng. Biotechnol.108: 95-120.

12. Voutilainen SP, Puranen T, Siika-Aho M, Lappalainen A, Alapuranen M, Kallio J, et al. 2008. Cloning, expression, and characterization of novel thermostable family 7 cellobiohydrolases. Biotechnol. Bioeng. 101: 515-528.

13. Taylor LE, Knott BC, Baker JO, Alahuhta PM, Hobdey SE, Linger JG, et al. 2018. Engineering enhanced cellobiohydrolase activity. Nat. Commun. 9: 1186.

14. Berka RM, Grigoriev IV, Otillar R, Salamov A, Grimwood J, Reid I, et al. 2011. Comparative genomic analysis of the thermophilic biomass-degrading fungi Myceliophthora thermophila and Thielavia terrestris. Nat. Biotechnol. 29: 922-927. 
15. Morozova VV, Gusakov AV, Andrianov RM, Pravilnikov AG, Osipov DO, Sinitsyn AP. 2010. Cellulases of Penicillium verruculosum. Biotechnol. J. 5: 871-880.

16. Linger JG, Taylor LE, Baker JO, Vander Wall T, Hobdey SE, Podkaminer K, et al. 2015. A constitutive expression system for glycosyl hydrolase family 7 cellobiohydrolases in Hypocrea jecorina. Biotechnol. Biofuels 8: 45.

17. Ma S, Preims M, Piumi F, Kappel L, Seiboth B, Record E, et al. 2017. Molecular and catalytic properties of fungal extracellular cellobiose dehydrogenase produced in prokaryotic and eukaryotic expression systems. Microb. Cell Fact. 16:37.

18. Dillon AJ, Bettio M, Pozzan FG, Andrighetti T, Camassola M. 2011. A new Penicillium echinulatum strain with faster cellulase secretion obtained using hydrogen peroxide mutagenesis and screening with 2-deoxyglucose. J. Appl. Microbiol. 111: 48-53.

19. Gusakov AV. 2011. Alternatives to Trichoderma reesei in biofuel production. Trends Biotechnol. 29: 419-425.

20. Zhang Z, Liu J-L, Lan J-Y, Duan C-J, Ma Q-S, Feng J-X. 2014. Predominance of Trichoderma and Penicillium in cellulolytic aerobic filamentous fungi from subtropical and tropical forests in China, and their use in finding highly efficient $\beta$-glucosidase. Biotechnol. Biofuels 7: 107 .

21. Arnthong J, Siamphan C, Chuaseeharonnachai C, Boonyuen N, Suwannarangsee S. 2020. Towards a miniaturized culture screening for cellulolytic fungi and their agricultural lignocellulosic degradation. J. Microbiol. Biotechnol. 30: 1670-1679.

22. Liu G, Zhang L, Wei X, Zou G, Qin Y, Ma L, et al. 2013. Genomic and secretomic analyses reveal unique features of the lignocellulolytic enzyme system of Penicillium decumbens. PLoS One 8: e55185.

23. Liu K, Lin X, Yue J, Li X, Fang X, Zhu M, et al. 2010. High concentration ethanol production from corncob residues by fed-batch strategy. Bioresour. Technol. 101: 4952-4958.

24. Du J, Zhang X, Li X, Zhao J, Liu G, Gao B, et al. 2018. The cellulose binding region in Trichoderma reesei cellobiohydrolase I has a higher capacity in improving crystalline cellulose degradation than that of Penicillium oxalicum. Bioresour. Technol. 266: 19-25.

25. Li S, Li G, Zhang L, Zhou Z, Han B, Hou W, et al. 2013. A demonstration study of ethanol production from sweet sorghum stems with advanced solid state fermentation technology. Appl. Energy 102: 260-265.

26. Song W, Han X, Qian Y, Liu G, Yao G, Zhong Y, et al. 2016. Proteomic analysis of the biomass hydrolytic potentials of Penicillium oxalicum lignocellulolytic enzyme system. Biotechnol. Biofuels 9: 68.

27. Qin Y, Zheng K, Liu G, Chen M, Qu Y. 2013. Improved cellulolytic efficacy in Penicilium decumbens via heterologous expression of Hypocrea jecorina endoglucanase II. Arch. Biol. Sci. 65: 305-314.

28. Gao L, Li Z, Xia C, Qu Y, Liu M, Yang P, et al. 2017. Combining manipulation of transcription factors and overexpression of the target genes to enhance lignocellulolytic enzyme production in Penicillium oxalicum. Biotechnol. Biofuels 10: 100.

29. Brown NA, Ries LNA, Goldman GH. 2014. How nutritional status signalling coordinates metabolism and lignocellulolytic enzyme secretion. Fungal Genet. Biol. 72: 48-63.

30. Hu Y, Xue H, Liu G, Song X, Qu Y. 2015. Efficient production and evaluation of lignocellulolytic enzymes using a constitutive protein expression system in Penicillium oxalicum. J. Ind. Microbiol. Biotechnol. 42: 877-887.

31. Hong J, Tamaki H, Yamamoto K, Kumagai H. 2003. Cloning of a gene encoding a thermo-stable endo-b-1,4-glucanase from Thermoascus aurantiacus and its expression in yeast. Biotechnol. Lett. 25: 657-661.

32. Szijártó N, Horan E, Zhang J, Puranen T, Siika-aho M, Viikari L. 2011. Thermostable endoglucanases in the liquefaction of hydrothermally pretreated wheat straw. Biotechnol. Biofuels 4: 2.

33. Vaaje-Kolstad G, Forsberg Z, Loose JS, Bissaro B, Eijsink VG. 2017. Structural diversity of lytic polysaccharide monooxygenases. Curr. Opin. Struct. Biol. 44: 67-76.

34. Gaber Y, Rashad B, Hussein R, Abdelgawad M, Ali NS, Dishisha T, et al. 2020. Heterologous expression of lytic polysaccharide monooxygenases (LPMOs). Biotechnol. Adv. 43: 107583

35. Greene ER, Himmel ME, Beckham GT, Tan ZP. 2015. Glycosylation of cellulases: Engineering better enzymes for biofuels. Adv. Carbohydr. Chem. Biochem. 72: 63-112.

36. Jeoh T, Michener W, Himmel ME, Decker SR, Adney WS. 2008. Implications of cellobiohydrolase glycosylation for use in biomass conversion. Biotechnol. Biofuels 1: 10.

37. Stals I, Sandra K, Geysens S, Contreras R, Van Beeumen J, Claeyssens M. 2004. Factors influencing glycosylation of Trichoderma reesei cellulases. I: Postsecretorial changes of the O- and N-glycosylation pattern of Cel7A. Glycobiology 14: 713-724.

38. Fägerstam LG, Pettersson LG. 1980. The 1.4- $\beta$-glucan cellobiohydrolases of Trichoderma reesei QM 9414. FEBS Lett. 119: 97-100.

39. Badino SF, Christensen SJ, Kari J, Windahl MS, Hvidt S, Borch K, et al. 2017. Exo-exo synergy between Cel6A and Cel7A from Hypocrea jecorina: Role of carbohydrate binding module and the endo-lytic character of the enzymes. Biotechnol. Bioeng. 114: 16391647.

40. Lombard V, Golaconda Ramulu H, Drula E, Coutinho PM, Henrissat B. 2014. The carbohydrate-active enzymes database (CAZy) in 2013. Nucleic Acids Res. 42: D490-D495.

41. Billard H, Faraj A, Lopes Ferreira N, Menir S, Heiss-Blanquet S. 2012. Optimization of a synthetic mixture composed of major Trichoderma reesei enzymes for the hydrolysis of steam-exploded wheat straw. Biotechnol. Biofuels 5: 9.

42. Martinez D, Berka RM, Henrissat B, Saloheimo M, Arvas M, Baker SE, et al. 2008. Genome sequencing and analysis of the biomassdegrading fungus Trichoderma reesei (syn. Hypocrea jecorina). Nat. Biotechnol. 26: 553-560.

43. Gusakov AV, Salanovich TN, Antonov AI, Ustinov BB, Okunev ON, Burlingame R, et al. 2007. Design of highly efficient cellulase mixtures for enzymatic hydrolysis of cellulose. Biotechnol. Bioeng. 97: 1028-1038.

44. Harris PV, Welner D, McFarland KC, Re E, Navarro Poulsen JC, Brown K, et al. 2010. Stimulation of lignocellulosic biomass hydrolysis by proteins of glycoside hydrolase family 61: structure and function of a large, enigmatic family. Biochemistry. 49: 33053316.

45. Ma L, Zhang J, Zou G, Wang C, Zhou Z. 2011. Improvement of cellulase activity in Trichoderma reesei by heterologous expression of a $\beta$-glucosidase gene from Penicillium decumbens. Enzyme Microb. Technol. 49: 366-371. 